Contacts

Publisher: Ben Crowe

Editor: Paul Smaglik

Marketing Manager: David Bowen

European Head Office,

London

The Macmillan Building

4 Crinan Street

London N1 9XW, UK

Tel +44 (0) 2078434961

Fax +44 (0) 2078434996

e-mail: naturejobs@nature.com

Naturejobs Sales Director

Nevin Bayoumi (4978)

UK/ RoW/ Ireland:

Matt Powell (4953)

Andy Douglas (4975)

Frank Phelan (4944)

Scandinavia/ Spain/ Portugal

Evelina Rubio Håkansson (4973)

Natureevents: Sille Opstrup (4994)

France/ Switzerland:

Amelie Pequignot (4974)

Production Manager: Billie Franklin

To send materials use London

address above.

Tel +44 (0) 2078434814

Fax +44 (0) 2078434996

e-mail: naturejobs@nature.com

Naturejobs web development:

Tom Hancock

Naturejobs online production

Stefan Hales

European Satellite Office

Germany/ Austria/ Italy/

The Netherlands/ Belgium

Patrick Phelan, Odo Wulffen

$\mathrm{Tel}+498954905711 /-2$

$\mathrm{Fax}+498954905720$

e-mail: p.phelan@nature.com

o.wulffen@nature.com

US Head Office, New York

345 Park Avenue South,

10th Floor, New York, NY 10010-1707

Tel +1 8009897718

Fax +18009897103

e-mail: naturejobs@natureny.com

US Sales Manager: Peter Bless

Japan Head Office, Tokyo

MG Ichigaya Building (5F),

19-1 Haraikatamachi,

Shinjuku-ku,

Tokyo 162-0841

Tel +81332678751

Fax +81332678746

Asia-Pacific Sales Director

Rinoko Asami

e-mail: rasami@naturejpn.com

\title{
naturejobs
}

\section{The power of goodbye}

- lias Zerhouni, director of the US National Institutes of

- Health, has come up with a simple way to improve the lot

of postdocs. It doesn't involve bureaucracy or legislation or extra pay - just more communication and a refusal by postdocs to accept bad situations. "The best thing is if the brightest mentees walk away from places that don't have good mentoring," Zerhouni told Naturejobs (for a complete transcript, see the Naturejobs graduate channel, www.nature.com/naturejobs/ channels/graduate).

Of course, Zerhouni isn't suggesting that postdocs quit their labs en masse in fits of pique. Rather, he says that before postdocs accept their fellowships, they should sit down with their prospective principal investigator and negotiate their mutual expectations. They can then draw up a sort of scientific "prenuptial agreement", Zerhouni says.

The understanding they reach should include agreement on how much career guidance the mentor will provide, as well as the amount of training that they can expect in such areas as presentation and grant-writing skills. Zerhouni adds that every postdoc will want something different from their mentor. Some prefer a hands-on approach with frequent reporting, whereas others may want a laissez-faire approach.

Zerhouni has a point. Postdocs have power in numbers. Their fellowships mark the last time in their career at which the supplyand-demand formula works in their favour. There are plenty of positions available, especially for postgrads who already have a good track record. Because postdocs need good publications and recommendations from a principal investigator to take the next step, it's essential that they find someone who will help them. And as Zerhouni says, if the principal investigator isn't willing to help, they should find another who will.

\section{Paul Smaglik}

Naturejobs editor

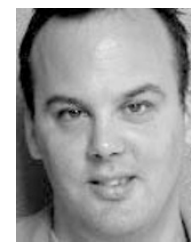

\section{Contents}

\section{CAREERS AND RECRUITMENT}

Molecular diagnostics set to expand

\section{WWW.NATUREJOBS.COM}

Career centre

Information on the scientific job market
FOCUS

SPOTLIGHT

RECRUITMENT

ANNOUNCEMENTS

EVENTS 